\title{
Implementasi Komunikasi Efektif Perawat-Dokter dengan Telepon di Ruang ICU Rumah Sakit Wava Husada
}

\section{Implementation of Nurse-Physician Effective Communication via Telephone in ICU Room of Wava Husada Hospital}

\author{
Fajar Nazri ${ }^{1}$, Siti Juhariah $S^{2}$, Muhammad Arif $S^{2}$ \\ ${ }^{1}$ Program studi Magister manajemen Rumah Sakit Fakultas Kedokteran Universitas Brawijaya Malang \\ ${ }^{2}$ Klinik Rawat Inap Muhammadiyah Sumberpucung \\ ${ }^{3}$ Rumah Sakit Wava Husada Kepanjen
}

\begin{abstract}
ABSTRAK
Komunikasi antara perawat dengan dokter melalui telepon di ruang ICU cenderung lebih berisiko terjadi kasus-kasus sentinel. Penelitian ini bertujuan untuk memberikan gambaran implementasi komunikasi efektif perawat-dokter melalui telepon dan pengalaman perawat berkomunikasi dengan dokter. Penelitian dilakukan dengan pendekatan studi observasional deskriptif terhadap perawat di ruang ICU. Pengukuran frekuensi implementasi komunikasi perawat dengan dokter melalui telepon dilakukan menggunakan lembar audit teknik komunikasi SBAR dan TBAK, dan survey menggunakan kuesioner. Hasil penelitian ini ditemukan komponen A (Assessment) merupakan komponen komunikasi SBAR dengan frekuensi terendah (21\%). Audit teknik komunikasi TBAK menemukan perawat tidak melakukan konfirmasi kembali (0\%) ketika berkomunikasi dengan dokter melalui telepon. Permasalahan yang dialami perawat ketika berkomunikasi dengan dokter diantaranya perawat sulit menghubungi dokter (50\%), dan perawat merasa mengganggu dokter sebelum berkomunikasi (50\%). Kebiasaan dokter berkomunikasi dan pembatasan waktu telepon ruangan merupakan situasi sulit yang sering dialami perawat saat berkomunikasi. Lemahnya kemampuan perawat berkomunikasi dan belum adanya pembakuan teknik komunikasi adalah faktor penghambat komunikasi efektif. Pengembangan standar komunikasi efektif dengan telepon $(n=8)$ dan pelatihan komunikasi bagi tenaga kesehatan $(n=7)$ merupakan dua solusi terpilih. Penelitian ini mengidentifikasi lemahnya komunikasi telepon terutama dalam aspek penilaiaan dan konfirmasi kembali yang dapat meningkatkan risiko insiden keselamatan. Ketiadaan teknik komunikasi yang baku dan kelemahan kemampuan perawat untuk berkomunikasi merupakan akar pemasalahan komunikasi telepon yang tidak efektif yang dapat dikelola dengan standar komunikasi dan pelatihan.
\end{abstract}

Kata Kunci: Dokter, ICU, komunikasi efektif, perawat, telepon

\begin{abstract}
Communication between nurses and physicians via telephone in the ICU room is more likely to be risky on the occurrence of sentinel cases. This study aims to provide an overview of nurse-physician effective communication implementation via telephone and nurses experience on communicating with physicians. This study uses a descriptive observational approach on the nurses in ICU room. The frequency measurement of nurse-physician communication implementation by telephone was using SBAR and TBAK communication technique audit sheet, and a survey using questionnaire. The result shows component A (Assessment) is a SBAR communication component with the lowest frequency (21\%). TBAK communication techniques audit finds nurses did not re-confirm (0\%) when communicating with physicians by phone. Problems experienced by nurses when communicating with physicians are that nurses feel difficult to contact physicians (50\%), and nurses feel bothering the physicians before communicating (50\%). Physicians' habits to communicate and time limitation are the difficult situations experienced by nurses. Inability of nurses to communicate and lack of standardization of communication techniques are factors inhibiting effective communication. Development of standardized effective communication via telephone $(n=8)$ and training for health personnel $(n=7)$ are the two chosen solutions. This study identifies the weakness of telephoning, especially in the aspect of scoring and re-confirmation that can increase the risk of security incidents. The absence of standardized communication techniques and the weakness of the nurses' ability to communicate are the root of problems on ineffective telephone communication that can be managed with standardized communication and training.
\end{abstract}

Keywords: Communication, ICU room, nurse, physician, telephone

Jurnal Kedokteran Brawijaya, Vol. 28, Suplemen No. 2, 2015; Korespondensi: Fajar Nazri. Program Studi Magister Manajemen Rumah Sakit Fakultas Kedokteran Universitas Brawijaya Malang, Jl. Veteran Malang 65145 Tel. (0341) 569117 Email:fajar_jihad@yahoo.com 


\section{PENDAHULUAN}

Komunikasi yangtidak efektif antara perawat dengan dokter merupakan hal yang paling sering disebutkan sebagai penyebab dalam kasus-kasus sentinel $(1,2)$. Hampir $70 \%$ kejadian sentinel yaitu kejadian yang mengakibatkan kematian atau cedera yang serius di rumah sakit disebabkan karena buruknya komunikasi $(1,3)$. Penelitian sebelumnya menjelaskan bahwa faktorfaktor yang menghambat komunikasi antara perawat dengan dokter, seperti: lemahnya struktur komunikasi, hirarki, bahasa, budaya, jenis kelamin dan perbedaan gaya komunikasi (4). Kegagalan komunikasi dengan telepon antara perawat dengan dokter bisa disebabkan oleh: ketidaksiapan perawat berkomunikasi (5), profesionalisme yang lemah (6-8), kolaborasi yang tidak adekuat (9), sulit ketika menghubungi dokter (10-12), kurangnya perhatian dokter saat ditelepon (12), dan kemampuan dokter menerima pesan dari perawat $(13,14)$.

Sasaran peningkatan komunikasi yang efektif merupakan salah satu kunci bagi staf untuk mencapai keselamatan pasien di rumah sakit. Keselamatan pasien termasuk salah satu sasaran dari standar akreditasi rumah sakit di Indonesia (15). Salah satu instalasi dalam rumah sakit dengan risiko insiden yang tinggi adalah perawatan intensif (Intensive Care Unit/ICU). Dalam penanganan kasus pasien kritis di ruang intensif, perawat dan dokter sering berkomunikasi melalui telepon dengan kebutuhan komunikasi yang akurat dan cukup waktu (16). Aktivitas komunikasi perawat dan dokter melalui telepon cenderung lebih mudah menyebabkan terjadinya kesalahan komunikasi $(17,18)$. Studi ini dilakukan untuk mengukur implementasi komunikasi efektif perawatdokter melalui telepon dan untuk mengetahui pengalaman perawat berkomunikasi dengan dokter di ruang ICU Rumah Sakit Wava Husada.

\section{METODE}

Metode yang digunakan adalah studi observasional deskriptif terhadap 12 perawat yang bertugas di ruang unit perawatan ICU (Intensive Care Unit) Rumah Sakit Wava Husada Kabupaten Malang, Jawa Timur. Survei dilaksanakan pada bulan Oktober 2014. Bentuk kegiatan observasi yaitu mengukur frekuensi implementasi komunikasi perawat-dokter melalui telepon dengan lembar audit teknik komunikasi SBAR (Situation, Background, Assessment, Recommendation) (19), TBAK (Tulis Kembali, Baca Kembali, Konfirmasi Kembali), dan kuesioner yang digunakan untuk menilai kepuasan perawat terhadap komunikasi perawat dengan dokter melalui telepon (15)

Kuesioner kepuasan komunikasi diadopsi dari The Schmidt nursing home quality of nurse-physician communication scale yang digunakan di Swedia (20). Alat ini telah dimodifikasi, divalidasi dan diuji realibilitas oleh Tjia et al untuk digunakan kepada perawat keluarga di Amerika Serikat (5). Kuesioner berisi 5 faktor dengan 5 skala Likert pertanyaan tertutup untuk mengetahui pengalaman perawat berkomunikasi dengan dokter melalui telepon. Faktor yang digunakan adalah kolaborasi, logistik, etika, hambatan bahasa, dan persiapan komunikasi. Kuesioner dilengkapi dengan pertanyaan terbuka untuk mengungkapkan informasi tentang: situasi masalah (misal: "Gambarkan situasi dimana Anda kesulitan berkomunikasi dengan dokter melalui telepon?"), hambatan komunikasi (misal: "Apa saja yang menghambat komunikasi yang efektif antara perawat dengan dokter melalui telepon ?"), dan solusi untuk mengefektifkan komunikasi (misal: "Apa saja yang dapat mengefektifkan komunikasi antara perawat dengan dokter melalui telepon ?"). Pertanyaan terbuka berdasarkan dari pengembangan oleh Tjia et al (5). Pembuatan analisis data menggunakan Microsoft Excel 2007 (Microsoft Corp USA).

\section{HASIL}

Terdapat 12 kuesioner terisi lengkap ( $\mathrm{N}=12)$. Sampel ini mewakili $86 \%$ dari perawat yang bertugas di ruang perawatan ICU. Data pada Tabel 1 menggambarkan sebaran responden terbesar menurut umur, yaitu perawat yang berumur $25-44$ tahun (83\%). Dari 12 responden diketahui bahwa $75 \%$ wanita dan $25 \%$ pria. Tingkat pendidikan responden terbanyak berasal dari Diploma 3 (D3) keperawatan (83\%). $100 \%$ responden berasal dari suku Jawa. Perawat yang bekerja selama 5-10 tahun (58\%) merupakan responden terbanyak yang mengisi kuesioner. Responden yang telah mengikuti sosialisasi patient safety (keselamatan pasien) sebanyak $42 \%$ dari total responden.

Tabel 1. Karakteristik responden

\begin{tabular}{cr}
\hline \multicolumn{1}{c}{ Karakteristik } & Responden (\%) \\
\hline Umur & \\
$18-24$ & 8 \\
$25-44$ & 83 \\
$45-64$ & 8 \\
Jenis Kelamin & \\
Pria & 25 \\
Wanita & 75 \\
Status pendidikan perawat & \\
D1 & 8 \\
D3 & 83 \\
S1 & 8 \\
Suku & \\
Jawa & 100 \\
Lama kerja (tahun) & \\
1 s/d 5 & 33 \\
5 sd 10 & 58 \\
$>10$ & 8 \\
Sosialisasi Patient Safety & \\
Ya & 42 \\
Tidak & 58 \\
\hline
\end{tabular}

Tabel 2 menggambarkan hasil observasi implementasi komunikasi perawat dengan dokter melalui telepon di ruang ICU dengan teknik komunikasi SBAR dan TBAK. Terdapat 14 kejadian proses komunikasi perawat dengan dokter di ruang ICU yang telah diamati. Komunikasi dengan telepon antara perawat dengan dokter dinilai tidak efektif karena frekuensi implementasi komponen teknik komunikasi SBAR dan TBAK tidak mencapai $100 \%$.

Komponen S (Situation) tercapai 79\% dan komponen B (Background) tercapai 64\%. Komponen A (Assessment) merupakan komponen dengan frekuensi terendah (21\%) diantara komponen teknik komunikasi SBAR. Pada audit teknik komunikasi TBAK diketahui perawat melakukan komponen B (Baca Kembali) sebesar 21\% dan tidak 
melakukan komponen K (Konfirmasi kembali) dengan frekuensi $0 \%$.

Tabel 2. Audit implementasi komunikasi perawat-dokter melalui telepon di ruang ICU

\begin{tabular}{lr}
\hline Teknik Komunikasi & Implementasi (\%) \\
\hline Teknik SBAR: & 79 \\
Situation (S) & 64 \\
Background (B) & 21 \\
Assessment (A) & 100 \\
Recommendation ( R ) & \\
Teknik TBAK: & 100 \\
Tulis Kembali (T) & 21 \\
Baca Kembali (B) & 0 \\
Konfirmasi Kembali (K) & \\
\hline
\end{tabular}

Tabel 3 menampilkan data tentang pengalaman perawat berkomunikasi dokter melalui telepon di ruang perawatan ICU berdasarkan faktor keterbukaan/kolaborasi, logistik, etika, hambatan bahasa, dan persiapan komunikasi. Pada faktor keterbukaan/kolaborasi diketahui pengalaman terbanyak bagi perawat, yaitu perawat merasa terburuburu berkomunikasi dengan dokter (33\%). Diketahui bahwa $8 \%$ perawat merasa dokter tidak ingin berurusan dengan masalah dan $8 \%$ perawat mengungkapkan bahwa dokter tidak mempertimbangkan pandangan perawat ketika membuat keputusan tentang pasien.

Pada aspek logistik ditemukan bahwa perawat sulit menghubungi dokter merupakan pengalaman yang sering diungkapkan oleh responden (50\%). Terdapat 25\% responden mengungkapkan bahwa perawat merasa tidak cukup waktu untuk mengatakan sesuatu kepada dokter. Kesulitan menemukan waktu yang tepat untuk menelpon dokter merupakan pengalaman yang diungkapkan oleh $25 \%$ responden. Ditemukan pula bahwa $8 \%$ perawat sulit menemukan tempat yang tenang.

Pada faktor etika terdapat 50\% responden mengungkapkan bahwa perawat akan mengantisipasi ketika dokter tidak senang atau tersinggung saat ditelepon. Responden kadang-kadang mengalami kondisi dimana dokter menghentikan pembicaraan telepon sebelum perawat mengakhiri laporan pasien (67\%), perawat merasa tidak dihormati setelah berinteraksi dengan dokter melalui telepon (17\%), perawat merasa frustasi setelah berinteraksi dengan dokter (17\%), dan perawat merasa dokter berkata tidak sopan ketika ditelepon (8\%).

Dari sisi hambatan bahasa ditemukan $8 \%$ responden sering mengalami kesulitan untuk mengerti apa yang dimaksud oleh dokter mengenai istilah medis. Responden kadang-kadang menemukan bahasa atau logat bahasa dokter yang sulit untuk dimengerti (8\%) dan merasa dokter sulit mengerti bahasa perawat saat bicara melalui telepon (17\%). Perawat merasa mengganggu dokter sebelum berkomunikasi melalui telepon merupakan pengalaman terbanyak yang diungkap oleh responden (50\%) dari segi persiapan komunikasi,dan perawat sering ragu-ragu sebelum menelpon dokter (17\%). Penyebab komunikasi telepon yang tidak efektif antara perawat dengan dokter yang dominan di ruang ICU adalah komunikasi yeng terburu-buru, waktu komunikasi yang tidak cukup, dokter menginterupsi pembicaraan telepon dan ketidaksiapan perawat sebelum menelpon dokter.

Tabel 3. Pengalaman perawat terhadap komunikasi perawat dengan dokter melalui telepon

\begin{tabular}{|c|c|c|c|}
\hline \multirow{2}{*}{ Pengalaman Perawat } & \multicolumn{3}{|c|}{ Frekuensi (\%) } \\
\hline & $\begin{array}{l}\text { Tidak } \\
\text { Pernah }\end{array}$ & Jarang & $\begin{array}{l}\text { Kadang - Sering Selalu } \\
\text { kadang }\end{array}$ \\
\hline
\end{tabular}

Keterbukaan/kolaborasi:

Saya merasa terburu-buru

berkomunikasi dengan dokter

melalui telepon

$\begin{array}{llllll}25 & 8 & 33 & 25 & 8\end{array}$

Saya merasa bahwa dokter tidak

ingin berurusan dengan masalah

yang dikomunikasikan melalui

telepon

Dokter tidak mempertimbangkan

pandangan perawat ketika

membuat keputusan tentang

pasien

Saya khawatir bahwa dokter

menginstruksikan sesuatu yang

tidak sesuai atau tidak perlu

Logistik:

Saya sulit menemukan tempat yang tenang untuk menelpon

dokter

Saya sulit menghubungi dokter

Saya merasa tidak cukup waktu untuk mengatakan sesuatu kepada dokter

Saya sulit menemukan waktu yang tepat untuk menelepon dokter

Etika:

Saya akan mengantisipasi ketika

dokter tidak senang atau

tersinggung saat ditelepon

Dokter menginterupsi

(menghentikan) pembicaraan

telepon sebelum saya mengakhiri

laporan pasien

Saya merasa tidak dihormati

setelah berinteraksi dengan dokter

melalui telepon

$\begin{array}{lllll}8 & 25 & 58 & 8 & 0\end{array}$

Saya merasa dokter berkata tidak

sopan ketika ditelepon tentang

pasien

Saya merasa frustasi setelah

berinteraksi dengan dokter

Hambatan bahasa:

Saya menemukan bahasa atau

logat bahasa dokter yang sulit

untuk dimengerti apa yang

diucapkannya

Saya sulit mengerti apa yang

dimaksud oleh dokter mengenai

istilah medis

Saya merasa dokter sulit mengerti

apa yang perawat ucapkan

mengenai bahasa atau logat

bahasa perawat

Persiapan komunikasi:

Saya merasa bahwa saya

mengganggu dokter

Saya ragu-ragu untuk menelepon dokter

$\begin{array}{lllll}0 & 42 & 50 & 8 & 0 \\ 8 & 33 & 58 & 0 & 0\end{array}$

$\begin{array}{ccccc}75 & 8 & 8 & 8 & 0 \\ 0 & 25 & 25 & 50 & 0 \\ 0 & 8 & 67 & 25 & 0 \\ 0 & 33 & 42 & 25 & 0 \\ 0 & 8 & 42 & 17 & 33\end{array}$

$\begin{array}{lllll}8 & 25 & 67 & 0 & 0 \\ 42 & 32 & 17 & 0 & 0 \\ 67 & 25 & 8 & 0 & 0 \\ 58 & 25 & 17 & 0 & 0\end{array}$

$\begin{array}{lllll}67 & 25 & 8 & 0 & 0\end{array}$

$\begin{array}{lllll}42 & 33 & 17 & 8 & 0\end{array}$

$\begin{array}{lllll}25 & 58 & 17 & 0 & 0\end{array}$

$\begin{array}{lllll}8 & 25 & 17 & 42 & 8 \\ 8 & 33 & 42 & 17 & 0\end{array}$


Kebiasaan dokter merupakan aspek terbanyak yang dinyatakan perawat dengan 12 respon yang diketahui dari (Tabel 4). Situasi yang sulit dialami perawat ketika berkomunikasi dengan dokter seperti: dokter sulit dihubungi pada waktu-waktu tertentu (bekerja atau malam hari), dokter terburu-buru saat ditelepon perawat dan beberapa dokter tidak suka ditelepon pada waktu tertentu. Diketahui pula ada 4 perawat berpendapat bahwa pembatasan waktu telepon ruangan ICU (3 menit) dan gangguan sinyal alat komunikasi termasuk situasi yang sulit bagi perawat dalam berkomunikasi.

Hambatan komunikasi terbanyak yang diungkap oleh perawat adalah lemahnya kemampuan perawat berkomunikasi. Perawat kurang melakukan persiapan, tidak terstruktur, dan kurang lengkap serta belum ditetapkan standar komunikasi merupakan pernyataan perawat mengenai masalah kemampuan komunikasi perawat.

Tabel 4. Pandangan perawat tentang komunikasi dengan dokter melalui telepon

\begin{tabular}{|c|c|c|}
\hline $\begin{array}{c}\text { Pandangan } \\
\text { perawat }\end{array}$ & $\begin{array}{l}\text { Tema (jumlah } \\
\text { respon) }\end{array}$ & Pernyataan langsung \\
\hline \multirow[t]{5}{*}{$\begin{array}{l}\text { Situasi yang } \\
\text { sulit }\end{array}$} & $\begin{array}{l}\text { Kebiasaan dokter } \\
(12)\end{array}$ & $\begin{array}{l}\text { Dokter sulit dihubungi melalui } \\
\text { telepon pada saat waktu istirahat, } \\
\text { bekerja dan malam hari }\end{array}$ \\
\hline & & $\begin{array}{l}\text { Dokter terburu-buru mengakhiri } \\
\text { komunikasi dengan perawat melalui } \\
\text { telepon }\end{array}$ \\
\hline & & $\begin{array}{l}\text { Beberapa dokter tidak suka } \\
\text { ditelepon pada waktu tertentu }\end{array}$ \\
\hline & Logistik (4) & $\begin{array}{l}\text { Pembatasan waktu sistem telepon } \\
\text { ruangan ICU ( } 3 \text { menit) }\end{array}$ \\
\hline & & $\begin{array}{l}\text { Gangguan sinyal alat komunikasi } \\
\text { dokter dan ruang ICU }\end{array}$ \\
\hline \multirow{4}{*}{$\begin{array}{l}\text { Hambatan } \\
\text { komunikasi }\end{array}$} & Kemampuan & Perawat kurang melakukan \\
\hline & $\begin{array}{l}\text { komunikasi perawat } \\
\text { (7) }\end{array}$ & $\begin{array}{l}\text { persiapan, tidak terstruktur, dan } \\
\text { kurang lengkap. Sehingga waktu } \\
\text { komunikasi perawat dengan dokter } \\
\text { menjadi lama } \\
\text { Belum ada standar komunikasi } \\
\text { perawat dengan dokter melalui } \\
\text { telepon }\end{array}$ \\
\hline & Hambatan waktu (5) & $\begin{array}{l}\text { Dokter tidak memiliki waktu yang } \\
\text { cukup untuk berkomunikasi lewat } \\
\text { telepon saat jam sibuk atau jam } \\
\text { istirahat sehingga waktu tunggu } \\
\text { untuk menelpon cukup lama }\end{array}$ \\
\hline & $\begin{array}{l}\text { Hambatan logistik } \\
\text { (4) }\end{array}$ & $\begin{array}{l}\text { Waktu telepon ruang ICU dibatasi } 3 \\
\text { menit }\end{array}$ \\
\hline \multirow[t]{5}{*}{$\begin{array}{l}\text { Solusi } \\
\text { komunikasi }\end{array}$} & $\begin{array}{l}\text { Kompetensi perawat } \\
\text { (8) }\end{array}$ & $\begin{array}{l}\text { Diadakan pelatihan standar } \\
\text { komunikasi perawat dengan dokter } \\
\text { melalui telepon }\end{array}$ \\
\hline & & $\begin{array}{l}\text { Perawat seharusnya melakukan } \\
\text { persiapan sebelum berkomunikasi }\end{array}$ \\
\hline & Organisasi (7) & $\begin{array}{l}\text { Pimpinan RS membuat standar } \\
\text { prosedur operasional untuk perawat } \\
\text { dan dokter }\end{array}$ \\
\hline & & $\begin{array}{l}\text { Pimpinan RS mengevaluasi } \\
\text { kebijakan mengenai pembatasan } \\
\text { waktu telepon agar komunikasi } \\
\text { telepon tidak terhambat }\end{array}$ \\
\hline & Perilaku Dokter (2) & $\begin{array}{l}\text { Dokter harus siap menerima telepon } \\
\text { dari perawat } \\
\text { Dokter mau bekerja sama dengan } \\
\text { perawat dalam komunikasi }\end{array}$ \\
\hline
\end{tabular}

Komunikasi telepon yang tidak efektif antara perawat dengan dokter di ruang ICU dapat disebabkan oleh beberapa faktor berdasarkan pengalaman dan pandangan perawat. Peneliti menggunakan Fish Bone Model untuk mengidentifikasi masalah (21). Faktor pertama adalah sumber daya manusia (manpower), seperti: dokter terburu-buru mengakhiri telepon, dokter sulit dihubungi, perawat mengganggu dokter ketika ditelepon, perawat mengantisipasi bila dokter tidak senang, perawat terburuburu dalam berkomunikasi, perawat kurang persiapan sebelum menelepon dokter,komunikasi perawat yang tidak terstruktur dan perawat ragu-ragu menelepon dokter. Faktor kedua berhubungan dengan fasilitas komunikasi (machine), seperti: pembatasan waktu telepon 3 menit dan gangguan sinyal pesawat telepon. Faktor ketiga berhubungan dengan sistem dan kebijakan (methode), seperti tidak ada standar prosedur operasional (SPO) komunikasi efektif dengan telepon.

Perawat terburu-buru berkomunikasi melalui telepon karena perawat tidak memiliki cukup waktu untuk berkomunikasi. Penyebabnya adalah pembatasan waktu telepon 3 menit, perawat kurang melakukan persiapan, dan informasi perawat yang tidak terstruktur. Semua faktor penyebab masalah komunikasi telepon yang tidak efektif tersebut disebabkan oleh belum adanya SPO komunikasi efektif dengan telepon. Akar masalah komunikasi telepon yang tidak efektif adalah belum adanya SPO komunikasi efektif dengan telepon.

Solusi menurut pandangan perawat ICU untuk menyelesaikan masalah komunikasi telepon yang tidak efektif, adalah: pelatihan komunikasi efektif, pembuatan SPO komunikasi efektif dengan telepon dan manajemen RS mengevaluasi kebijakan pembatasan waktu telepon.Pelatihan standar komunikasi perawat $(n=8)$ merupakan solusi yang diberikan perawat yang terbanyak untuk memperbaiki komunikasi perawat dengan dokter. Tujuh perawat berpendapat bahwa pimpinan RS membuat standar prosedur operasional dan mengevaluasi kebijakan pembatasan waktu telepon sebagai solusi komunikasi.

\section{DISKUSI}

Komunikasi telepon antara perawat dengan dokter di ruang ICU dinilai tidak efektif karena implementasi metode SBAR-TBAK tidak mencapai 100\%. Diketahui implementasi metode SBAR yang tidak mencapai $100 \%$, adalah: komponen situation (79\%), background (64\%), assessment (21\%). Metode TBAK yang tidak mencapai $100 \%$, adalah: komponen baca kembali (21\%) dan konfirmasi kembali (0\%). Komponen Assessment merupakan komponen yang jarang dilakukan oleh perawat ketika berkomunikasi dengan dokter melalui telepon. Hal yang sama ditemukan pula oleh Zhu et al, bahwa komponen alat komunikasi SBAR dengan frekuensi terendah yang dilakukan oleh perawat adalah Assessment (22). Komponen baca kembali dan konfirmasi kembali sering tidak dilakukan oleh perawat ketika menelpon dokter. Hal ini akan menimbulkan medical error dan insiden keselamatan pasien (23).

Permasalahan komunikasi yang tidak efektif disebabkan oleh beberapa faktor. Studi ini menemukan bahwa perawat sering mengalami masalah komunikasi dokter melalui telepon karena persoalan kolaborasi, logistik, etika, bahasa, dan persiapan komunikasi. Hal yang sama juga dari temuan studi-studi terdahulu yang mengungkapkan faktor-faktor yang mempengaruhi masalah komunikasi perawat dengan dokter melalui telepon, seperti: profesionalisme yang lemah (6-8), 
kolaborasi yang tidak adekuat (9), sulit ketika menghubungi dokter (10-12), dan kurangnya perhatian dokter saat ditelepon (12).

Perawat mengungkapkan bahwa dokter memiliki kemampuan menerima pesan melalui telepon yang rendah, seperti keterbatasan waktu yang dimiliki dokter dalam menerima pesan dan ketidaktertarikan dokter menerima telepon dari perawat. Studi sebelumnya menemukan hal yang sama mengenai rendahnya kemampuan dokter menerima pesan dari perawat $(13,14)$. Studi ini menemukan bahwa penyebabnya adalah dokter tidak memiliki cukup waktu berkomunikasi karena kesibukan aktivitas pekerjaannya.Permasalahan perawat sulit menghubungi dokter dapat menyebabkan persiapan komunikasi oleh perawat kurang optimal. Hal ini dapat mempengaruhi daya ingat manusia yang terbatas (24). Untuk mendapakan informasi penting dari dokter, perawat kurang suka menunggu lama untuk berbicara kepada dokter melalui telepon (5). Akibatnya perawat sering menunda pelaksanaan tanggung jawab harian keperawatannya, sehingga terhambatnya pelayanan pasien (24).

Ketidaksiapan perawat berkomunikasi dengan dokter juga diketahui dapat menghambat komunikasi. Kompetensi dan kemampuan perawat mempersiapkan komunikasi merupakan komponen kunci keberhasilan komunikasi antara perawat dengan dokter dengan telepon. Kualitas persiapan komunikasi perawat termasuk komponen terpenting. Tjia et al menemukan bahwa perawat melakukan persiapan sebelum menelepon dokter dapat mewujudkan komunikasi yang efektif (5).

Kebiasaan dokter yang juga ditemukan di dalam studi ini, adalah dokter menghentikan pembicaraan selama telepon, dokter terburu-buru berkomunikasi, dan perilaku dokter yang tidak sopan. Kebiasaan dokter tersebut telah dijelaskan oleh studi-studi sebelumnya $(6,7)$. Penyebabnya adalah waktu komunikasi dokter yang terbatas. Perilaku dokter yang mengganggu ini memiliki hubungan yang kuat dengan keselamatan pasien (patient safety) di rumah sakit, terutama penyebab terjadinya kejadian yang tidak diiharapkan (KTD) $(24,25)$. Beberapa studi terdahulu telah menemukan bahwa penghentian pembicaraan di tengah komunikasi telepon memiliki dampak negatif terhadap alur kerja,(26) komunikasi (27), isi komunikasi (28), penyelesaian tugas (29), bangsal rawat inap (30), dan kejadian tidak diharapkan (31) di ruang ICU.

Faktor perawat terburu-buru berkomunikasi ketika menelpon dokter disebabkan oleh komunikasi perawat yang dibatasi waktu telepon. Waktu telepon ruangan dibatasi 3 menit. Diketahui teknik komunikasi SBAR mampu mengefektifkan waktu komunikasi antara perawat dengan dokter kurang dari 1 menit (22). Keterbatasan waktu yang dimiliki dokter dan pembatasan waktu telepon rumah sakit 3 menit merupakan faktor penyebab terburu-burunya komunikasi antara perawat dan dokter.

\section{DAFTAR PUSTAKA}

1. Alvarado K, Lee R, Christoffersen E, et al.Transfer of Acountability: Transforming Shift Handover to Enhance Patient Safety. Health Care Quarterly. 2006; 9:75-79.

2. Angood P. Why The Joint Comission Cares About
Akar permasalahan komunikasi telepon yang tidak efektif di ruang ICU adalah belum adanya SPO komunikasi efektif dengan telepon antar tenaga kesehatan. Tujuan SPO adalah agar berbagai proses kerja rutin terlaksana dengan efisien, efektif, seragam, dan aman, serta meningkatkan mutu pelayanan (32). SPO komunikasi efektif dapat sebagai standar untuk meningkatkan komunikasi telepon yang efektif.

Pembakuan SPO komunikasi efektif dan pelatihan komunikasi merupakan solusi yang diungkapkan responden untuk meningkatkan komunikasi efektif dengan telepon antara perawat dengan dokter. Standarisasi model teknik komunikasi terutama di ruang ICU dapat membantu perawat berpikir dan menyiapkan informasi ke dokter dan membantu dokter menerima informasi penting untuk lebih fokus, sehingga dapat mengurangi aspek komunikasi yang tidak penting (33-35).

Model teknik komunikasi yang secara umum digunakan di pelayanan kesehatan adalah pendekatan SBAR (Situation, Background, Assessment, and Recommendation) (36), dan pendekatan TBAK (Tulis Kembali, Baca Kembali, dan Konfirmasi Kembali) (15). Renz et al mengungkapkan bahwa model teknik komunikasi SBAR membantu perawat untuk mengorganisasi cara berpikir, mengorganisasi informasi, dan merasa lebih percaya diri berkomunikasi dengan dokter (36). Model teknik komunikasi TBAK memiliki manfaat yaitu untuk mengurangi insiden keselamatan pasien.(15) Barenfanger et al menemukan bahwa perawat membaca kembali informasi ketika menelepon dokter dapat menurunkan risiko medical error dan meningkatkan keselamatan pasien (23).

Pelatihan komunikasi bagi perawat merupakan solusi yang diungkapkan responden untuk mengatasi masalah komunikasi telepon yang tidak efektif. Renz et al menemukan bahwa pelatihan komunikasi yang dilengkapi dengan skenario kasus dan latihan praktek komunikasi sangat membantu untuk meningkatkan komunikasi efektif dan keselamatan pasien (36).

Studi ini menunjukkan bahwa komponen Assessment merupakan komponen SBAR dengan frekuensi terendah yang dilakukan perawat saat berkomunikasi dengan dokter. Perawat jarang membaca kembali dan tidak melakukan konfirmasi kembali ketika menerima pesan dari dokter melalui telepon. Perawat sering terburu-buru berkomunikasi dengan dokter, sulit menghubungi dokter, mengantisipasi bila dokter tidak senang, merasa dirinya mengganggu dokter dan ragu-ragu menelpon dokter. Ketidaksiapan perawat ketika berkomunikasi, keterbatasan waktu yang dimiliki dokter dan pembatasan waktu telepon rumah sakit merupakan faktor penyebab komunikasi yang tidak efektif. Akar permasalahan adalah rumah sakit belum memiliki standar komunikasi efektif dengan telepon yang dapat diatasi dengan membuat standar prosedur operasional (SPO) komunikasi efektif dengan telepon dengan ditunjang pelatihan.

Handoffs Strategy. (Online) 2007. https://www.rmf. harvard.edu/ /media/Files/_Global/KC/Forums/200 7/forumMar2007.pdf.

3. Haig KM, Sutton S, and Whittington J. SBAR: A Shared Mental Model for Improving Communication between Clinicians. The Joint Commission Journal on Quality 
and Patient Safety. 2006;32(3):167-175.

4. De Meester K, Verspuy M, Monsieurs KG, and Van Bogaert P. SBAR Improves Nurse-Physician Communication and Reduces Unexpected Death: A Pre and Post Intervention Study. Resuscitation. 2013;84(9):1192-1196.

5. Tjia J, Mazor KM, Field T, Meterko V, Spenard A, and Gurwitz JH. Nurse-Physician Communication in the Long-Term Care Setting: Perceived Barriers and Impact on Patient Safety. Journal of Patient Safety. 2009; 5(3): 145-152.

6. Rosenstein $\mathrm{AH}$ and O'Daniel M. A Survey of the Impact of Disruptive Behaviors and Communication Defects on Patient Safety.The Joint Commission Journal on Quality and Patient Safety. 2008; 34(8): 464-471.

7. Rosenstein $\mathrm{AH}$ and O'Daniel M. Disruptive Behavior and Clinical Outcomes: Perceptions of Nurses and Physicians. American Journal of Nursing. 2005; 105: 54-64.

8. Cadogan MP , Franzi C, Osterweil D, and Hill T. Barriers to Effective Communication in Skilled Nursing Facilities: Differences in Perception between Nurses and Physicians. Journal of the American Geriatrics Society. 1999; 47(1): 71-75.

9. McMahan EM, Hoffman K, and McGee GW. PhysicianNurse Relationships in Clinical Settings: A Review and Critique of the Literature, 1966-1992.Medical Care Research and Review. 1994; 51(1): 83-112.

10. McKnight LK, Stetson PD, Bakken S, Curran C, and Cimino JJ. Perceived Information Needs and Communication Difficulties of Inpatient Physicians and Nurses.Journal of the American Medical Informatics Association. 2002; 9(6): S64-S69.

11. Kayser-Jones JS, Wiener CL, and Barbaccia JC. Factors Contributing to the Hospitalization of Nursing Home Residents. The Gerontologist. 1989; 29(4): 502-510.

12. Miller DB, Brimigion J, Keller D, and Woodruff S. Nurse-Physician Communication in a Nursing Home Setting. The Gerontologist. 1972; 12(3): 225-229.

13. Prescott PA and Bowen SA. Physician-Nurse Relationships. Annals of Internal Medicine. 1985; 103(1): 127-133.

14. Thomas EJ, Sexton JB, and Helmreich RL. Discrepant Attitudes about Teamwork among Critical Care Nurses and Physicians. Critical Care Medicine. 2003; 31(3): 956-959.

15. Komisi Akreditasi Rumah Sakit. Standar Akreditasi Rumah Sakit. Jakarta: KARS;2011.

16. Woodhall LJ, Vertacnik L, and McLaughlin M. Implementation of the SBAR Communication Technique in a Tertiary Center. Journal of Emergency Nursing. 2008;34(4):314-317.

17. RabøI LI, Andersen ML, Østergaard D, Bjørn B, Lilja B, and Mogensen T. Descriptions of Verbal Communication Errors between Staff. An Analysis of 84 Root Cause Analysis-Reports from Danish Hospitals. British Medical Journal Quality \& Safety. 2011; 20(3): 268-274
18. World Health Organization. Communication During Patient Hand-Over. Patient Safety Solution. (Online) 2007. http://www.who.int/patientsafety/ solutions/patientsafety/PS-Solution3.pdf

19. Institute for Health Care Improvement. SBAR Technique for Communication: A Situational Briefing Model. (Online). http://www.ihi.org/resources/ Pages/Tools/SBARTechniqueforCommunicationASitu ationalBriefingModel.aspx.

20. Ouslander JG, Lamb G, Tappen R, et al. Interventions to Reduce Hospitalizations from Nursing Homes: Evaluation of the INTERACT /I Collaborative Quality Improvement Project. Journal of the American Geriatrics Society. 2011;59(4):745-753.

21. Ishikawa K. Guide to Quality Control. Tokyo: Asian Productivity Organization; 1976.

22. Zhu H, McCrea N, and Kelsall W. G188 Improving the Paediatric Handover: Quality, Safety and SBAR. Archives of Disease in Childhood. 2014;99(Suppl 1): A82.

23. Barenfanger J, Sautter RL, Lang DL, Collins SM, Hacek DM, and Peterson LR. Improving Patient Safety by Repeating (Read-Back) Telephone Reports of Critical Information. American Journal of Clinical Pathology. 2004; 121(6):801-803.

24. Parker J and Coiera E. Improving Clinical Communication: A View From Psychology.Journal of the American Medical Informatics Association. 2000;7(5):453-461.

25. Zimmer JG and Watson NM. Physician Response to Notification of Acute Problems in Nursing Homes. Journal of the American Geriatrics Society. 1991;39(4):348-352.

26. Brixey JJ, Robinson DJ, Turley JP, and Zhang J. The Roles of MDs and RNs as Initiators and Recipients of Interruptions in Workflow. International Journal of Medical Informatics. 2010;79(6):109-115.

27. Coiera E and Tombs V. Communication Behaviours in a Hospital Setting: An Obser-Vational Study. British Medical Journal. 1998;316(7132):673-676.

28. Coiera EW, Jayasuriya RA, Hardy J, Bannan A, and Thorpe ME. Communication Loads on Clinical Staff in the Emergency Department. The Medical Journal of Australia. 2002;176(9):415-418.

29. Westbrook JI, Coiera E, Dunsmuir WT, et al. The Impact of Interruptions on Clinical Task Completion.British Medical Journal Quality \& Safety. 2010;19(4):284-289.

30. Alvarez G and Coiera E. Interruptive Communication Patterns in the Intensive Care Unit Ward Round.International Journal of Medical Informatics. 2005;74(10):791-796.

31. Grundgeiger $\mathrm{T}$ and Sanderson P. Interruptions in Healthcare: Theoretical Views. International Journal of Medical Informatics. 2009;78(5):293-307.

32. Komisi Akreditasi Rumah Sakit. Panduan Penyusunan Dokumen Akreditasi. Jakarta: KARS; 2012: hal. 14.

33. Whitson HE, Hastings SN, Lekan DA, Sloane R, White $\mathrm{HK}$, and McConnell ES. A Quality Improvement Program to Enhance After-Hours Telephone 
Communication between Nurses and Physicians in a Long-Term Care Facility. Journal of the American Geriatrics Society. 2008; 56(6): 1080-1086.

34. Dunsford J. Structured Communication: Improving Patient Safety with SBAR. Nursing for Women's Health. 2009;13(5):384-390.

35. Marshall S, Harrison J, and Flanagan B. The Teaching of a Structured Tool Improves the Clarity and Content of Interprofessional Clinical Communication. British Medical Journal Quality \& Safety. 2009;18(2):137-140.

36. Renz SM, Boltz MP, Wagner LM, Capezuti EA, and Lawrence TE. Examining the Feasibility and Utility of an SBAR Protocol in Long-Term Care. Geriatric Nursing. 2013; 34(4): 295-301. 